\title{
PRODUKSI UJARAN ANAK DOWN SYNDROME DI SLB NEGERI PEMBINA KOTA MATARAM
}

\author{
${ }^{1}$ Ahyati Kurniamala Niswariyana ${ }^{2}$ Baiq Desi Milandari \\ Dosen Program Studi Pendidikan Bahasa dan Sastra Indonesia \\ FKIP Universitas Muhammadiyah Mataram \\ aludragisel@gmail.com
}

\begin{abstract}
ABSTRAK
Down syndrome merupakan kelainan yang terjadi pada manusia akibat dari jumlah kromosom berbeda dengan manusia pada umumnya. Penelitian ini bertujuan untuk mendeskripsikan: 1) bentuk kata dan kalimat yang mampu diujarkan anak down syndrome, dan 2) pengaruh lingkungan terhadap perkembangan produksi ujaran anak down syndrome. Penelitian ini menggunakan metode kualitatif deskriptif. Dalam penelitian ini, peneliti akan memfokuskan pada bentuk kata dan kalimat, serta pengaruh lingkungan terhadap perkembangan produksi ujaran. Subjek penelitian adalah anak penyandang down syndrome usia 5-10 tahun di SLB Negeri Pembina Kota Mataram. Data diperoleh melalui metode observasi, metode simak, metode cakap, dan metode perekaman. Analisis data dilakukan dengan reduksi data yang kemudian dilanjutkan dengan penyajian data, dan terakhir verifikasi.
\end{abstract}

Kata Kunci: Psikolinguistik, Produksi Ujaran, Down Syndrome

\section{PENDAHULUAN}

Setiap manusia mempunyai kesempatan yang sama dalam memperoleh bahasa, baik verbal maupun nonverbal. Akan tetapi pada kenyataannya, tidak selamanya anak terlahir dianugerahi kemampuan berbahasa secara normal, namun ada juga yang abnormal. Kemampuan berbahasa abnormal yang dimaksud adalah kemampuan berbahasa yang disebabkan oleh gangguan secara fisik maupun mental sehingga mengakibatkan keterlambatan dalam perkembangan produksi ujaran. Salah satu keterlambatan perkembangan bahasa yang disebabkan oleh gangguan fisik dan mental adalah down syndrome. Keterbelakangan fisik dan mental pada penyandang down syndrome menyebabkan timbulnya keterlambatan perkembangan kemampuan ujaran (Rondal, 1998).Penyandang down syndrome memiliki kekurangmampuan memproduksi ujaran dalam komunikasi verbal. Kekurangmampuan tersebut dapat dilihat dari kurangnya perbendaharaan kata-kata, kelemahan artikulasi, kebiasaan untuk berbicara dengan mempergunakan kata-kata yang terpisah (Sidiarto dalam Baihaqi, 2011: 154).

Dr Eva Chundrayetti, SpA (K) mengatakan usia ibu ketika hamil merupakan salah satu factor risiko down syndrome. Penyebab down syndrome secara pasti belum diketahui. Namun berdasarkan penelitian usia ibu ketika hamil berkaitan erat dengan terjadinya down syndrome. Ia menjelaskan seorang 
ibu yang hamil terlalu muda dan terlalu tua dapat berisiko melahirkan anak dengan down syndrome. Umur terlalu muda untuk hamil dan melahirkan itu berkisar di bawah 20 tahun dan terlalu tua di atas 35 tahun. Down syndrome sendiri menurutnya adalah kelainan genetik, di mana pada orang normal setiap inti sel memiliki 23 pasang kromosom, yang berasal dari kedua orang tuanya. Dalam keadaan normal, masing-masing kromosom dari nomor 1 sampai nomor 23 berjumlah sepasang. Akan tetapi pada down syndrome, jumlah kromosom pada nomor 21 berjumlah $\quad 3$ kromosom. (m.republika.co.id)

Seperti kasus yang terjadi pada Kenzo, seorang anak istimewa dengandown syndrome. Kenzo terlahir pada saat ibunya berusia 38 tahun, saat ini Kenzo berusia 5 tahun.

Perkembangan produksi ujaran pada Kenzo tentu berbeda dengan anak normal seusianya. Anak normal pada usia 5 tahun telah mampu membuat kalimat lengkap dalam percakapan sehari-hari. Pada kasus ini, Kenzo mengalami keterlambatan dalam hal kemampuan verbal. Kenzo saat ini mampu berkomunikasi dengan keluarganya dengan bahasa yang sederhana seperti, kata mami, papi, oma, jatuh, ambin (ambil), Eca (nama kakaknya), mamah (panggilan untuk bude).

Berangkat dari penjelasan di atas, peneliti ingin mengetahui bagaimana perkembangan ujaran anak dengandown syndromedalam menghasilkan ujaran bentuk kata dan kalimatyang lebih kompleks. Di samping itu, peneliti ingin mengetahui apakah ada pengaruh dari lingkungan sekitar yang dapat meningkatkan perkembangan produksi ujaran.

Peneliti membatasi penelitian ini pada anak penyandang down syndrome usia 512 tahun. Hal ini bertujuan untuk membatasi data agar tidak terlalu meluas. Selain itu, usia 5-12 tahun merupakan golden age dan masa peralihan dari usia prasekolah menuju usia sekolah. Oleh karena itu, peneliti mengangkat judul tentang Studi Psikolinguistik pada Perkembangan Produksi Ujaran Anak Down syndrome. Berdasarkan uraian di atas, penelitian ini bertujuan untuk mendeskripsikan bentuk kata dan kalimat yang mampu diujarkan anak down syndrome dan menjelaskan pengaruh lingkungan terhadap perkembangan produksi ujarananak down syndrome.

\section{METODE PENELITIAN}

Subjek penelitian yaitu anak penyandang down syndrome usia 5-10 tahun. Pengambilan subjek peelitian dilakukan dengan menggunakan teknik purposive sampling. Alasan pemilihan usia 5-10 adalah pada usia tersebut anak berada pada fase golden age dan masa peralihan dari usia prasekolah menuju usia sekolah. Penelitian ini dilaksanakan di SLB Negeri Pembina Kota Mataram. Metode yang digunakan pada penelitian ini adalah metode kualitatif. Bungin (2001:124) mengatakan bahwa data yang menggunakan metode kualitatif diungkapkan dalam bentuk kalimat serta uraian-uraian, bahkan dapat berupa cerita pendek. Adapun penelitian ini bersifat deskriptif, sebab merupakan penggambaran ujaran bentuk kata dan kalimat yang diserap dari keluarga dan 
lingkungannya dalam bentuk percakapan yang kemudian dianalisis ke bentuk narasi.

Data dalam penelitian ini diperoleh dari hasil rekaman percakapan anak penyandang down syndromedengan orang tua, guru, maupun lingkungan sekitarnya. Dalam hal ini yang digunakan sebagai data adalah bahasa yang keluar dari tuturan subjek secara langsung. Dengan kata lain, semua bentuk tuturan (kata dan kalimat) yang keluar dari ujaran subjek itulah yang digunakan sebagai data.

Data yang akan digunakan dalam penelitian ini adalah data deskriptif kualitatif yaitu data berupa rekaman dan ditranskripsikan ke dalam bentuk tulisan. Adapun sumber data yang digunakan dalam penelitian ini adalah sumber data primer yaitu sumber data pertama dimana sebuah data dihasilkan.Apabila data yang didapat dari sumber data pertama terbatas, digunakan pula sumber data sekunder (Bungin, 2001:129). Sumber data sekunder digunakan karena keterbatasan data dari subjek atau untuk mengetahui maksud ujaran yang dihasilkan oleh subjek.

Dalam penelitian ini akan digunakan beberapa metode dan teknik pengumpulan data, yaitu metode observasi, metode simak, dan metode cakap.

Metode analisis data yang digunakan adalah metode analisis deskriptif kualitatif dengan cara melakukan reduksi data terlebih dahulu. Mereduksi data berarti merangkum, memilih hal-hal yang pokok, memfokuskan pada hal-hal yang penting, dicari tema dan polanya, dan membuang yang tidak perlu (Sugiyono, 2010: 338). Setelah mereduksi data, langkah selanjutnya adalah penyajian data. Dalam penelitian kualitatif, penyajian data lebih sering dilakukan dengan teks yang bersifat naratif. Terkait dengan penelitian yang akan dilakukan, langkahlangkah yang dilakukan oleh peneliti dalam menganalisis data adalah (a) mendeskripsikan data rekaman perbincangan anak penyandang down syndrome dengan orang tua, guru, maupun lingkungannya, (b) memilahmilah kata dan kalimat yang mampu diucapkan penyandang DS, (c) menginterpretasikan data yang telah didapat sesuai dengan permasalahan yang dianalisis, (d) merumuskan dan menyimpulkan hasil analisis yang telah diperoleh.

\section{HASIL DAN PEMBAHASAN}

Bentuk Kata Dan Kalimat Anak Down Syndrome

Produksi Ujaran di Kelas 1 (Usia 5-8 tahun)

$>$ Situasi, obrolan, dan respon di kelas dan luar kelas.

Peneliti : siapa namanya nak ? (bertanya pada seorang anak DS perempuan bernama Intan).

Intan : ta (membuka mulut lebar, tanpa keluar suara) dibantu ibunya menyebutkan namanya "Intan". Ibu Intan menjelaskan perkembangan anaknya, dikatakan bahwa di rumah Intan sudah bisa diajak berkomunikasi, akan tetapi sulit mengucapkannya. Dikatakan ibunya bahwa Intan sudah mampu mengucapkan banyak kata, seperti maem, mama, papa, dan jika diminta melakukan sesuatu sudah bisa dilakukan. Akan tetapi hal berbeda kami dapat dari 
guru kelasnya, bahwa Intan belum mampu mengucapkan kata dasar utuh, harus dibantu persukukata, itupun dengan dilihat pelafalan dari mulut guru. Namun untuk instruksi Intan cukup mampu melakukannya.

Anak DS selanjutnya yang peneliti wawancarai bersama ibunya, bernama Wendi. Wendi cukup mampu merespon setiap ucapan peneliti.

Peneliti : hallo sayang...siapa namanya ? (sapa peneliti sambil mendekati kerumunan orang tua yang sedang berkumpul, menyapih anak-anaknya).

Ibu Wendi : Wen....? (sambil menunggu respon anaknya).

Wendi : Ndi...(ucap Wendi melanjutkan perkataan ibunya).

Selanjutnya Wendi diberikan buku dan pensil. Sang ibu meminta Wendi menulis namanya, hasilnya Wendi bisa menulis namanya sendiri. Cukup baik motoriknya. Wendi cukup mampu diajak berkomunikasi dengan baik, beberapa kata mampu diucapkan seperti "mera=kamera", "ape =HP", "mamak", "ulis=tulis", "uku=buku", "tas", "map=maaf". Wendi memahami perkataan orang tanpa perlu mengulang $2 \mathrm{x}$.

Satu anak DS lagi yang peneliti ajak berkomunikasi di luar kelas, bernama Fatin. Fatin cukup aktif dan usil. Saat diminta menyebut namanya, Fatin mampu mengucapkan "Atin", "ni" saat memberikan ibunya tempat makannya, "mak" panggilan untuk ibunya. Dalam memahami ucapan orang, diperlukan 2 sampai 3 kali pengulangan. Fatin cukup aktif untuk hal motorik, Fatin beberapa kali meminta difoto karena melihat peneliti memegang kamera.
Situasi di dalam kelas tidak jauh berbeda dengan yang peneliti temui di luar kelas. Di kelas anak-anak lebih banyak dilatih untuk kemandirian, seperti berjalan di atas bidang yang kecil tanpa bantuan, dilatih ke kamar mandi sendiri, menyikat gigi, mengikat tali sepatu sendiri tanpa bantuan guru maupun orang tua. Anak-anak menikmati permainan di kelas, meski beberapa anak mengganggu temannya. Di kelas 1 , ada 5 anak yang down syndrome. Pada permainan ini, guru memberikan CD yang bertuliskan angka, siswa diminta menghitung angka tersebut, kemudian mengambil jepitan jemuran sejumlah angka yang sudah disebutkan.

Guru : Intan...angka berapa ini ? (pancing bu Mimi sambil memberikan CD yang telah ditulis angka).

Intan : u, a, ga (sambil menunjuk angkaangka yang ada).

Guru : iya..satu, dua, tiga, yeeee....pinteeeerrr...sekarang ambil jepitannya 3, terus jepit CDnya (sambil mengajarkan cara menjepit CD). Sudah...sekarang Wendi, ayo Wen...

Wendi : tu, wa, ga, pat, ma...ima (kata Wendi sembari mengangkat telapak tangannya).

Guru : iya...pinter Wendi, 5 ya, sekarang ambil jepitannya 5 Wen (instruksi guru, patuh diikuti Wendi). Fatin, mana Fatin, ayo Tin hitung dulu ini (kata bu Mimi). Akan tetapi Fatin tidak mengindahkan kata-kata bu Mimi, dia asyik menggelendot pada peneliti, penasaran ingin melihat hasil kamera yang peneliti pegang.

Guru : Fatin, ndak boleh, ayo sini itung dulu (kata gurunya). Lagi-lagi Fatin tak menghiraukan ucapan gurunya. Akhirnya 
anak-anak diminta duduk melingkar dan bernyanyi "aku, diriku sendiri".

Guru : aku, diriku sendiri. Tunjuk matamu, tunjuk hidungmu, tunjukkan tanganmu, mana tangannya...tunjuk. Tunjuk telingamu, tunjuk mulutmu, tunjukkan kakimu, mana kakinya...

Anak-anak merespon dengan sangat baik. Menunjukkan semua bagian tubuh yang disebutkan dalam lagu. Meski tidak semua anak ikut mengeluarkan suara saat bernyanyi, akan tetapi anak-anak memahami yang diinginkan lagu tersebut dengan menunjukkan bagian tubuh mereka satu persatu sambil mengamati guru.

\section{Hasil analisis}

Berdasarkan data yang peneliti dapatkan pada kelas 1 (antara usia 5-8 tahun) bahwa anak DS pada usia tersebut telah mampu mengucapkan kata dasar dengan pelafalan per suku kata, kata yang mampu diucapkannya pun terbatas. Ada juga yang sama sekali belum mampu mengucapkan kata "verbal". Namun demikian, anak-anak DS mampu mengkomprehensi perkataan maupun perintah orang yang mengajaknya bicara. DS sedang-ringan sudah mampu mengucapkan kata dasar dengan jelas, meski masih dibantu memancing dengan suku kata awal, lalu si anak melanjutkan suku kata akhirnya. DS sedang-berat sama sekali belum mampu berkomunikasi secara verbal, ucapan lawan bicarapun belum mampu dikomprehensi dengan reaksi.

Jadi anak DS pada kelas 1, belum mampu mengucapkan kata utuh, dan belum mampu mengucapkan kalimat. Untuk mengungkapkan keinginan mereka dibantu dengan gerakan tangan (bahasa isyarat).

\section{Produksi Ujaran di Kelas 2 (Usia 7-9 tahun)}

$>$ Situasi, obrolan, dan respon di kelas

Peneliti : sayang...siapa namanya?

Anak lain : Aji (memberitahu peneliti)

Peneliti : kenalan tante sayang, salim sayang, Ajiii....(menyapa anak)

Aji : (diam saja, tidak memberi reaksi apa-apa, ekspresi seperti mengantuk)

Peneliti terus berusaha membangun komunikasi dengan anak.

Peneliti : salim sayang..kenalan dong tante sayang..salim sayang (sembari menyodorkan tangan ke anak)

Aji : (merespon dengan menjulurkan tangannya, menjangkau tangan peneliti). Anak Lain : dia seneng plastik dia..

Peneliti : (mencoba membangun kembali komunikasi dengan Aji ((DS1)) dia seneng plastik nak?

Aji : (Respon yang diberikan Aji hanya menguap, memainkan tangannya, memasukkan ke mulut, sambil menatap kosong kea rah peneliti).

Peneliti : (melanjutkan pancingan dengan mengajak ngobrol Aji) "ini siapa yang duduk dī sini Ji ? oohh...Aji duduk sama Hawa ya ? iya ? ee...Aji duduk sama Hawa ya?"

Aji : (merespon pertanyaan peneliti dengan menggeleng-gelengkan kepala sambil senyum-senyum).

Peneliti : (melanjutkan obrolan) cantik ya Hawa ya ? (menunggu reaksi Aji, akan tetapi Aji kembali merespon dengan geleng-geleng kapala).

Setelah itu guru memulai pembelajaran dan sibuk dengan anak yang lain.

Peneliti tetap memusatkan perhatian pada Aji. Aji tidak memperhatikan ketika guru memberikan stimulus berupa pertanyaan yang dilemparkan kepada semua siswa. Aji 
terlihat mengantuk, menguap beberapa kali, memainkan jemarinya, menjilat-jilat jemarinya, lalu tiduran di meja. Sejauh itu taka da kata-kata yang keluar dari mulut Aji. Aji tertidur di kelas. Setelah bangun, Guru menyapa Aji, mengajak ngobrol, Aji hanya merespon dengan menggleng-gelengkan kepalanya.

Bu Wulan : Hallo Ji, hi bangun...eh liat bu guru...(sambil memegang kedua tangan Aji).

Aji merespon dengan menggelenggelengkan kepalanya menghindari tatapan bu Wulan.

$\mathrm{Bu}$ Wulan : Hallo Ji, hey...hallo Ji assalamualaikum...Aji nggak sekolah ? sudah bangun ? ayoo...iya...tu liat tementemennya lagi belajar.

(Aji menolehkan kepalanya ke sana ke mari).

$\mathrm{Bu}$ Wulan : ei...tos dulu...tos...tos...(sambil mengangkat dan memegang kedua telapak tangan Aji). Tu liat Wawa. (Aji menoleh ke arah Hawa, melirik sebentar lalu geleng-geleng lagi). Hawa datang terlambat, begitu masuk ia langsung menempati tempat duduknya. Bu Wulan bertanya ke Hawa.

Guru : Wawa dianter siapa?

Hawa : bunda

Guru : berapa saudaranya Wawa?

Hawa : bunda

Guru : siapa nama kakaknya?

Hawa : bunda

Guru : mana bukunya Wa?

Hawa geleng kepala, lalu memilih tiduran di meja.

Di kelas 2, ada 3 anak yang down syndrome.

$>$ Hasil analisis

Kemampuan berkomunikasi anak

DS kelas 2 (usia 7-9 tahun) tidak mengalami kemajuan cukup baik dari komunikasi verbal kelas 1, dapat dilihat dari data yang kami dapat di atas, anak DS pada kelas ini hanya 2 orang, yang 1 DS berat, hanya mampu mengkomprehensi ucapan lawan bicara namun belum mampu mengucapkan kata secara utuh. Anak DS kedua di kelas ini, sudah mampu mengucapkan kata dasar dengan jelas, mampu menjawab pertanyaan, akan tetapi tidak fokus pada esensi pertanyaan laan bicara.

Jadi anak DS pada kelas 2, belum mampu mengucapkan kata utuh, dan belum mampu mengucapkan kalimat. Untuk mengungkapkan keinginan mereka dibantu dengan gerakan tangan (bahasa isyarat).

\section{Produksi Ujaran di Kelas 3 (Usia 8-12 tahun)}

>situasi, obrolan, dan respon di kelas

Di kelas sedang terjadi proses belajar mengajar, guru terlihat sibuk membagikan kertas bergambar lambinglambang pada burung garuda. Anak-anak tampak asyik dengan kesibukan masingmasing. Seorang anak DS sedikit terganggu saat peneliti merekamnya, "aaa" kata yang diucapkan hanya itu, lalu fokus kembali ke kertas yang diberikan guru. Seorang anak DS lain bernama Refan berjalan menuju jendela, ingin keluar, peneliti berusaha memancing obrolan. Peneliti sempat memintanya duduk, akan tetapi tak dihiraukan. Dia tetap berdiri di jendela menghadap luar. Peneliti akhirnya mendekati Refan dan mengajaknya ngobrol.

Peneliti : tos...tos dulu nak sayang...

Reaksi yang diberikan hendak mengambil kamera yang peneliti gunakan untuk merekamnya. 
Saat sedang istirahat seorang anak DS bernama Bayu tengah ditenangkan pengasuhnya, bobot badan Bayu $3 \mathrm{x}$ bobot teman seusianya. Bayu tampak gerah, jadi agak gelisah dan tak tenang. Peneliti mengamati komunikasi yang terjadi antara Bayu dan pengasuhnya, tak terlalu jelas apa yang diucapkan pengasuhnya, secara emosional pengasuhnya tampak menenangkan Bayu yang sedang mengamuk, melepas baju seragamnya, berusaha membuangnya, namun ditahan oleh pengasuhnya, "ndak...ndak...ndak boleh..." ucap pengasuhnya, Bayu merespon dengan mengucapkan katakata lirih "ma...ma...ma..." dengan nada kesal. Pengasuhnya mengelus-elus tangan Bayu, memeluknya, mengelus pipinya, menciumnya dengan kasih sayang. Akhirnya Bayu tenang dan mau mengikuti kata-katanya. Sejauh itu belum ada kata-kata lengkap yang diucapkan Bayu. Usia Bayu 9 tahun.

Di kelas 3 (kelas tuna grahita) ada 5 dari 8 anak yang down syndrome.

$>$ Hasil analisis

Anak DS di kelas 3, berjumlah 5 dari 7 orang siswa. Dari pengamatan peneliti selama proses belajar mengajar di kelas, siswa DS mengerti apa yang diucapkan guru, berusaha memahami perintah guru. Untuk komunikasi vebal, meski sudah kelas 3 atau bertambah usia, anak DS di kelas 3 ini, belum mampu mengucapkan 2 kata secara utuh, masih tetap berbicara satu kata per suku kata saja, belum mengalami perkembangan yang signifikan. Anak DS mampu berinteraksi dengan temannya satu sama lain. Perkembangan yang paling menonjol dari kelas 3 adalah, mereka sudah bisa diatur, cukup mandiri, mengikuti, mampu mengikuti perintah guru.

Jadi anak DS pada kelas 1, belum mampu mengucapkan kata utuh, dan belum mampu mengucapkan kalimat. Untuk mengungkapkan keinginan mereka dibantu dengan gerakan tangan (bahasa isyarat).

\section{Pengaruh Lingkungan Terhadap Perkembangan Produksi Ujaran Anak Down Syndrome}

>Lingkungan Keluarga

Lingkungan keluarga merupakan rumah ajar pertama bagi anak-anak. Bagi anak DS keluarga merupakan bagian terpenting dalam hidup mereka, tanpa dukungan keluarga anak-anak istimewa ini tak bisa apa-apa. Berdasarkan hasil pengamatan peneliti, orang tua terlalu memanjakan anak-anak mereka. Siapapun orang tua akan melakukan hal yang sama pada anak-anaknya, yang normal sekalipun. Apalagi anak berkebutuhan khusus seperti mereka. Kemandirian yang diharapkan pada anak DS sedikit terhambat karena sikap protektif orang tua terhadap anakanaknya.

>Lingkungan Sekolah

Lingkungan sekolah membawa dampak positif bagi perkembangan anak DS. Guru-guru di sekolah mengajarkan mereka untuk bisa mandiri. Paling tidak hidup mereka yidak terlalu bergantung pada orang lain, syukur jika mampu berprestasi dan membanggakan keluarganya. Lingkungan sekolah membawa pengaruh besar pada perkembangan mental anak DS, dari yang apa-apa minta bantuan orang tua dan keluarga, di skolah mereka diajarkan untuk bisa melakukan kegiatan pribadi 
sendiri. SLB Pembina Mataram mendukung kebutuhan anak-anak DS.

Dalam hal komunikasi, guru dengan sabar mengajarkan anak-anak DS untuk melafalkan kata demi kata, menginstruksi mereka untuk dapat memahami apa yang dikatakan gurunya.

Hal masih menjadi masalah antara pihak sekolah dan orang tua adalah kurangnya perhatian dan dukungan orang tua atas tujuan pihak sekolah untuk mejadikan siswa mandiri, orang tua terus-terusan memanjakan anak-anak mereka dalam segala hal, sedang di sekolah saja para orang tua senantiasa membantu anak-anak mereka, meskipun pada dasarnya anakanak telah mampu melakukannya sendiri.

\section{PENUTUP}

Berdasarkan hasil penelitian di atas, dapat disimpulkan sebagai berikut. Pertama, Anak DS kelas rendah belum mampu mengucapkan kata dasar secara utuh, mereka masih perlu dibantu dalam mengucapkan beberapa kata yang kurang familiar bagi mereka. Adapun kata-kata yang mampu diucapkan ialah kata yang terdiri dari dua suku kata, untuk mengucapkannya secara utuh pun mereka dibantu guru atau orang tuanya. Ada beberapa anak DS yang mampu mengucapkan kata dasar secara utuh, akan tetapi kosakata mereka sangat terbatas. Anak DS mampu memahami apa yang diinstruksikan kepada mereka. Anak DS dapat mengkomprehensi maksud lawan bicaranya, serta melakukan perintah dengan baik, hanya saja keterbatasan mereka pada bahasa verbal yang belum sempurna. Anak DS pada kelas rendah belum mampu mengucapkan kalimat, untuk mengungkapkan maksud dan keinginan mereka juga menggunakan bahasa isyarat dengan gerakan tangan dan mulut. Kedua, Keberadaan lingkungan keluarga dan sekolah sangat membantu perkembangan anak DS, lingkungan keluarga mengajarkan mereka tentang kasih sayang dan kesabaran, lingkungan sekolah mengajarkan mereka bersosialisasi dan kemandirian. Akan tetapi yang masih menjadi kendala antara pihak sekolah dan orang tua adalah masih adanya miss-komunikasi antara tujuan sekolah membentuk anak yang mandiri dan keluarga yang masih memanjakan anak.

\section{DAFTAR PUSTAKA}

Arifuddin. 2013. Neuropsikolinguistik. Jakarta: Rajawali Pers

Arikunto, Suharmini. 2009. Manajemen Penelitian. Jakarta: Rineka Cipta

Bachtiar, Muhammad Yusri. 2013. Kemampuan Memproduksi Ujaran Anak Balita (Suatu Kajian Psikolinguistik). Ikhtiyar, Vol. 11, No. 1 hlm. 137-146

Baihaqi, M. Lutfi. 2011. Kompetensi Fonologis Anak Penyandang Down syndrome di SLB C Negeri 1 Yogyakarta [Versi elektronik]. Widyariset, Vol. 14, No. 1 hlm. 153162

Bogdashina, 0. 2005. Communication Issue in Autism and Asperger Syndrome: Do We Speak the Same Language. London: Jessica Kingsley Publishers

Bungin, Burhan. 2001. Metodologi Penelitian Sosial (Format-format Kuantitatif dan Kualitatif). 
Surabaya: Airlangga University Press

Chaer, Abdul. 2009. Psikolinguistik: kajian teori. Jakarta: Rineka Cipta

Chundrayetti, Eva. Usia Kehamilan Ibu Pengaruhi Faktor Risiko Down Syndrome. Diunduh melalui https://www.republika.co.id (edisi Thursday, 22 March 2018) pada tanggal 19 juli 2018

Dardjowidjojo, Soenjono. 2010. Psikolinguistik: pengantar pemahaman bahasa manusia. Jakarta: Yayasan Obor Indonesia http://eprints.ums.ac.id/26696/3/BAB II.pdf. Diunggah pada 23 April 2016

Imandala, Iim. 2012. Perkembangan Bahasa pada Anak Tunagrahita. Diunduh melalui https://pendidikankhusus.wordpr ess.com/2012/03/27/perkemban gan-bahasa-pada-anak-

tunagrahita/ pada tanggal 23 April 2016

Indah, Rohmani Nur. 2011. Gangguan Berbahasa Kajian Pengantar. Malang: UIN-Maliki Press.

Kridalaksana, Harimurti. 2008. Kamus linguistik, Edisi Keempat. Jakarta: PT Gramedia Pustaka Utama

Mahsun.2007. Metode Penelitian Bahasa (Tahapan Strategi, Metode, dan Tekniknya). Jakarta: PT Raja Grafindo Persada.

Nugroho, D. A., Gangguan Pemahaman Bahasa pada Anak Down Syndrome. Diunduh melalui http://txwicara.blogspot.co.id/2009/04/ga ngguan-pemahaman-bahasa-padaanak.html pada tanggal 23 April 2016
Rondal, J. A. $1998 . \quad$ Cases of Exceptional Language In Mental Retardation and Down syndrome:Explanatory Perspectives. Down SyndromeResearch and Practice: Vol 5. No 1. Hlm 1-15. Great Britain: The Down syndromeEducational Trust

Scovel, Thomas. 1998. Psycholinguistics. New York: Oxford University Press

Steinberg, D.D. 1982. Psycholinguistics: language, mind, and word. New York: Longman

Tarigan, Henry Guntur. 1988. Pengajaran pemerolehan bahasa. Jakarta: Departemen Pendidikan dan Kebudayaan.

Tarigan, Henry Guntur. 2011.

Pengajaran Pemerolehan Bahasa.Bandung: Angkasa 